\title{
Influence of Integrated Nutrient Management on Growth and Yield of Maize (Zea mays)
}

\author{
Krishnakhi Borah*, Rinjumoni Dutta and Khagen Kurmi \\ Department of Agronomy, Assam Agricultural University, Jorhat-785013, India \\ *Corresponding author
}

\begin{tabular}{|l|}
\hline Ke y w o r d s \\
Nutrient \\
Management, \\
Growth and yield, \\
Maize (Zea mays)
\end{tabular}

A B S T R A C T

\begin{abstract}
A field experiment was conducted at Instructional-cum-Research Farm (ICR) of Assam Agricultural University, Jorhat during summer season of the year 2016 to evaluate the varietal response and integrated nutrient management practice for growth and yield of maize. The experiment was laid out in split plot design and replicated thrice. The soil of the experimental site was sandy loam in texture, acidic in reaction ( $\mathrm{pH} 4.94)$, medium in organic carbon $(0.72 \%)$, low in available $\mathrm{N}(159 \mathrm{~kg} / \mathrm{ha})$ and $\mathrm{P}_{2} \mathrm{O}_{5}(23.78 \mathrm{~kg} / \mathrm{ha})$ and medium in available $\mathrm{K}_{2} \mathrm{O}(160.5 \mathrm{~kg} / \mathrm{ha})$. Two composite variety of maize viz., RCM-76 and DA-61-A were sown in $18^{\text {th }}$ of March (2016) and harvested by two picking on $24^{\text {th }}$ June and $4^{\text {th }}$ July. Experimental findings revealed that the two varieties did not differ significantly, however DA-61-A variety showed better response to different INM treatments. INM practices influenced the growth characters of maize in terms of number of leaves per plant and all yield attributing character of maize. 50\% RD of $\mathrm{N}$ through fertilizer $+50 \% \mathrm{~N}$ replaced by enriched compost $\left(\mathrm{I}_{6}\right)$ recorded the highest values for all crop physiological parameters (LAI, LAD and chlorophyll content). Similarly, the yield attributing characters viz., weight of cob with and without husk, length of cob, average diameter of cob, number of rows/cob, grain/row, grain/cob, 1000 grain weight, weight of grain per cob, yield (cob and stover yield) of maize was observed to be highest under 50\% $\mathrm{RD}$ of $\mathrm{N}$ through fertilizer $+50 \% \mathrm{~N}$ replaced by EC $\left(\mathrm{I}_{6}\right)$. The highest grain and stover yield being $39.8 \mathrm{q} / \mathrm{ha}$ and $78.4 \mathrm{q} / \mathrm{ha}$ respectively was produced from $\mathrm{I}_{6}(50 \% \mathrm{RD}$ of $\mathrm{N}$ through fertilizer $+50 \% \mathrm{~N}$ replaced by $\mathrm{EC}$ ) treatment.
\end{abstract}

\section{Introduction}

Maize is one of the most versatile crop having wider adaptability under varied agro-climatic condition. Maize is the third most important food grain in India. Maize has higher genetic potential than other cereal crops. It is called as "miracle crop" and also "queen of cereals". Maize is considered as a promising crop for diversifying agriculture in upland areas of
India. In India maize is grown on 8.49 million ha with production and productivity of 21.29 $\mathrm{mt}$ and $2.51 \mathrm{t} / \mathrm{ha}$ respectively. In India, about $28 \%$ of maize produce is used for food purpose, about $11 \%$ as livestock feed, $48 \%$ as poultry feed, $12 \%$ in wet milling industry and $1 \%$ as seed.

The soil and climatic conditions of Assam are very much suitable for maize cultivation. In 
Assam, maize occupies an area of only about 20 thousand hectare. The total area and productivity is very low in comparison to other states of India. The productivity of maize has been about $7 \mathrm{q} / \mathrm{ha}$ which is very less from the all India average. Maize is grown, in the state, primarily for human consumption only.

As a heavy feeder of nutrients, maize productivity is largely dependent on nutrient management. Therefore it needs fertile soil to express its yield potential. Chemical fertilizers are the primary source of plant nutrient. But soils which received plant nutrient only through chemical fertilizer are showing declining productivity despite being supplied with sufficient nutrients. Excessive use of chemical fertilizer has been associated with decline in soil physical and chemical properties and crop yield and significant land problem such as degradation due to over exploitation of land, soil pollution caused by high application rates of fertilizer and pesticide application (Singh, 2000). Highest productivity of crops in sustainable manner without deteriorating the soil and other natural resources could be achieved only by applying appropriate combination of different organic manures and inorganic fertilizers (Chandrashekara et al., 2000). An integrated use of inorganic and biofertilizers should be opted for maximizing economic yield and to improve soil health (Syed Ismail et al., 2001). So it is important to identify the best type of available organic resources which can be used as fertilizers and their best combination with appropriate proportion of inorganic fertilizers.

\section{Materials and Methods}

A field experiment was conducted for the year 2016 in the summer season on maize at Instructional Cum Research Farm of Assam Agricultural University, Jorhat, India. The climate of the area is sub-tropical with hot summer and cold winter. The total amount of rainfall received during the period of experimentation was $1106.10 \mathrm{~mm}$ with a maximum average weekly rainfall of 258.6 $\mathrm{mm}$ on $16^{\text {th }}$ to $22^{\text {nd }}$ April, 2016.

The weekly mean maximum temperature ranged from $33.5^{\circ} \mathrm{C}$ to $24.9^{\circ} \mathrm{C}$ and the weekly mean minimum temperature ranged from $26.1^{\circ} \mathrm{C}$ to $16.0^{\circ} \mathrm{C}$ during the crop growing period. The weekly average relative humidity during the morning hour ranged from 97 per cent to 88 per cent and in evening ranged from 91 per cent to 51 per cent. The two maize varieties (RCM-76 and DA-61-A developed from Barapani, Meghalaya) were sown on $18^{\text {th }}$ March (2016) at a spacing of $60 \mathrm{~cm} \times 20 \mathrm{~cm}$ and harvested by two picking at $24^{\text {th }}$ June and $4^{\text {th }}$ July (2016).

Representative soil samples were collected prior to the experiment to study the initial soil physico-chemical properties of the experimental plot. The soil was sandy loam in texture, acidic in reaction ( $\mathrm{pH} 4.94)$, medium in organic carbon $(0.72 \%)$, low in available $\mathrm{N}$ $(159 \mathrm{~kg} / \mathrm{ha})$, low in available $\mathrm{P}_{2} \mathrm{O}_{5}(23.78$ $\mathrm{kg} / \mathrm{ha})$ and medium in $\mathrm{K}_{2} \mathrm{O}(160.5 \mathrm{~kg} / \mathrm{ha})$.

Experimental plots, $14.4 \mathrm{~m}^{2}(4.8 \mathrm{~m} \times 3 \mathrm{~m})$ in size, were arranged in a split plot design and each treatment was carried out in triplicate.

The treatments consisted of two varieties RCM-76 and DA-61-A in main plot and seven INM practices viz., $0 \mathrm{~kg}$ NPK/ha $\left(\mathrm{I}_{1}\right), 60-40$ $40 \mathrm{~kg} \quad \mathrm{NPK} / \mathrm{ha}$ (RDF) $\left(\mathrm{I}_{2}\right), \quad \mathrm{RDF}+$ Azospirillum $+\operatorname{PSB}\left(\mathrm{I}_{3}\right), 50$ per cent $\mathrm{N}$ through chemical fertilizer+50 per cent replaced by vermicompost $\left(\mathrm{I}_{4}\right), 75$ per cent $\mathrm{N}$ through chemical fertilizer+25 per cent replaced by vermicompost $\left(\mathrm{I}_{5}\right), 50$ per cent $\mathrm{N}$ through chemical fertilizer+50 per cent replaced by enriched compost $\left(\mathrm{I}_{6}\right), 75$ per cent $\mathrm{N}$ through chemical fertilizer +25 per cent replaced by enriched compost $\left(\mathrm{I}_{7}\right)$ in sub plots. 
$\mathrm{N}$ was applied in 2 split doses. First top dressing was done at knee height stage and second was before tasseling. Enriched compost was applied in respective plots 19 days prior to sowing and vermicompost was applied in respective plots one day before sowing. Seed of maize were treated with Azospirillum + PSB 12hrs before sowing and sown in respective plot. Gap filling was done whenever necessary.

The data were analyzed statistically and the mean differences among the treatment means were evaluated by the split plot design at $5 \%$ level of probability.

\section{Results and Discussion}

Crop growth in terms of plant height, number of leaves per plant, leaf area index, leaf area duration and chlorophyll content were monitored which were not significantly influenced by different varieties. These parameters were also not significantly influenced by different INM treatment except leaf area duration and leaf area index. In case of 100 per cent chemical fertilizer, the nutrient losses especially $\mathrm{N}$ through leaching, volatilization and denitrification affected the nutrient availability to plant.

Different yield and yield attributing characters such as, weight of cob with and without husk, length of cob without husk, average diameter of cob without husk, rows/cob, grains/row, cob and stover yield, harvest index of maize were studied. There was no significant difference found between the two varieties in all the cases. But in case of 1000 grain weight and grain weight per cob variety DA-61-A gave better result which was statistically significant over RCM-76 variety. Yield attributes and yield of maize were significantly influenced by different INM practices. The highest weight of cob with or without husk, length of cob, average diameter of cob, rows per cob, grain per row, grain per cob, 1000-grain weight were found in INM practice as compared to RDF and control practice. All the parameters related to yield characters under INM practices were found to be statistically significant over RDF and control practice. This might be due to the availability of nutrient in soil. The availability of nitrogen in soil might be due to its direct addition and slow release of the nutrient through organic manures as observed by Kumari et al., (2010). The increase in available phosphorus might be due to the organic acids, which were released during microbial decomposition of organic matter and help in solubility of native phosphates as a result of which increase in phosphorus was recorded. Moreover, the higher availability of potassium in soil may be due to beneficial effect of organic manures on the reduction of potassium fixation and release potassium due to interaction of organic with clay. Similar results were reported by Das et al., (2004).

These factors contributed to higher yield under INM practices. The yield of cob and stover, harvest index were found higher In case of DA-61-A variety (33.00 q/ha, $65.33 \mathrm{q} / \mathrm{ha}$ and $30.30 \%$ respectively) than the RCM-76 variety (31.62 q/ha, $65.12 \mathrm{q} / \mathrm{ha}$ and $32.50 \%$ respectively). The highest cob weight was recorded in $\mathrm{I}_{6}$ treatment which was $56.06 \%$ higher than the control and $25.99 \%$ higher than the RDF treatment. It clearly showed that integration of organic and inorganic sources improved the nutrient use efficiency by plant; as a result the maize yield was increased. Mugwe et al., (2009) reported that application of organic combination with inorganic fertilizer produced significantly higher maize yields than with only inorganic fertilizer. This is more likely because organic manures application not only improves soil physical propreties but also enhances microbial activities and provides stable supply of both micro and macro nutrients (Table 1-3). 
Table.1 Effect of varieties and INM practices on LAI, LAD and chlorophyll content of maize

\begin{tabular}{|c|c|c|c|c|c|c|c|}
\hline \multirow[t]{2}{*}{ TREATMENT } & \multicolumn{3}{|c|}{ Leaf area index } & \multicolumn{2}{|c|}{$\begin{array}{l}\text { Leaf area } \\
\text { duration } \\
\text { (days) }\end{array}$} & \multicolumn{2}{|c|}{$\begin{array}{l}\text { Chlorophyll content (mg/g } \\
\text { fresh leave weight) }\end{array}$} \\
\hline & $\begin{array}{c}30 \\
\text { DAS }\end{array}$ & $\begin{array}{c}45 \\
\text { DAS }\end{array}$ & $\begin{array}{c}60 \\
\text { DAS }\end{array}$ & $\begin{array}{c}45 \\
\text { DAS }\end{array}$ & $\begin{array}{c}60 \\
\text { DAS }\end{array}$ & $\begin{array}{l}\text { VEGETATI } \\
\text { VE STAGE }\end{array}$ & $\begin{array}{l}\text { REPRODUC } \\
\text { TIVE } \\
\text { STAGE }\end{array}$ \\
\hline \multicolumn{8}{|l|}{ VARIETY (V) } \\
\hline $\mathrm{V}_{1}=\mathrm{RCM}-76$ & 1.76 & 3.30 & 5.29 & 64.20 & 90.74 & 3.13 & 6.35 \\
\hline$V_{2}=D A-61-A$ & 1.79 & 3.50 & 5.34 & 65.86 & 92.45 & 3.13 & 6.35 \\
\hline S.Ed.( \pm$)$ & 0.051 & 0.132 & 0.043 & 2.34 & 1.65 & 0.03 & 0.11 \\
\hline C.D (0.05) & NS & NS & NS & NS & NS & NS & NS \\
\hline \multicolumn{8}{|l|}{$\begin{array}{l}\text { INTEGRATED } \\
\text { NUTRIENT } \\
\text { MANAGEMENT } \\
\text { PRACTICES (I) }\end{array}$} \\
\hline$I_{1}=0 \mathrm{~kg} / \mathrm{ha}$ & 1.59 & 2.81 & 4.68 & 54.10 & 77.21 & 3.11 & 6.36 \\
\hline $\mathrm{I}_{2}=60-40-40 \mathrm{~kg} / \mathrm{ha}(\mathrm{RDF})$ & 1.77 & 3.32 & 5.21 & 63.05 & 88.88 & 3.12 & 6.36 \\
\hline $\begin{array}{l}\mathrm{I}_{3}=\mathrm{RDF}+\text { Azospirillum }+ \\
\text { PSB }\end{array}$ & 1.84 & 3.71 & 5.53 & 69.39 & 97.05 & 3.13 & 6.30 \\
\hline $\begin{array}{l}\mathrm{I}_{4}=\mathbf{5 0} \% \mathrm{RD} \text { of } \mathbf{N} \text { through } \\
\text { fertilizer }+\mathbf{5 0 \%} \text { replaced } \\
\text { by VC }\end{array}$ & 1.79 & 3.46 & 5.24 & 65.26 & 91.18 & 3.11 & 6.36 \\
\hline $\begin{array}{l}\mathrm{I}_{5}=75 \% \mathrm{RD} \text { of } \mathrm{N} \text { through } \\
\text { fertilizer }+25 \% \text { replaced } \\
\text { by VC }\end{array}$ & 1.81 & 3.59 & 5.46 & 67.41 & 94.79 & 3.12 & 6.35 \\
\hline $\begin{array}{l}\mathrm{I}_{6}=\mathbf{5 0} \% \mathrm{RD} \text { of } \mathrm{N} \text { through } \\
\text { fertilizer }+\mathbf{5 0 \%} \text { replaced } \\
\text { by EC }\end{array}$ & 1.82 & 3.74 & 5.57 & 69.81 & 97.93 & 3.15 & 6.36 \\
\hline $\begin{array}{l}\mathrm{I}_{7}=75 \% \mathrm{RD} \text { of } \mathrm{N} \text { through } \\
\text { fertilizer }+25 \% \text { replaced } \\
\text { by EC }\end{array}$ & 1.80 & 3.52 & 5.52 & 66.21 & 94.14 & 3.14 & 6.37 \\
\hline S.Ed.( \pm$)$ & 0.088 & 0.152 & 0.200 & 2.56 & 2.8 & 0.07 & 0.17 \\
\hline C.D. (0.05) & NS & 0.261 & 0.341 & 4.38 & 4.78 & NS & NS \\
\hline \multicolumn{8}{|l|}{ INTERACTION (V X I) } \\
\hline S.Ed. $( \pm)$ & 0.125 & 0.216 & 0.282 & 3.624 & 3.956 & 0.094 & 0.234 \\
\hline C.D.(0.05) & NS & NS & NS & NS & NS & NS & NS \\
\hline
\end{tabular}


Table.2 Effect of varieties and INM practices on No. of rows per, grains per row, grains per cob, wt. of cob with and without husk (g/cob), length of cob $(\mathrm{cm})$ and Av. Diameter of cob $(\mathrm{cm})$

without husk

\begin{tabular}{|c|c|c|c|c|c|c|c|}
\hline TREATMENT & $\begin{array}{c}\text { No. of } \\
\text { rows } \\
\text { per cob }\end{array}$ & $\begin{array}{l}\text { Grains } \\
\text { per row }\end{array}$ & $\begin{array}{l}\text { Grains } \\
\text { per cob }\end{array}$ & $\begin{array}{l}\text { Wt. of } \\
\text { cob } \\
\text { with } \\
\text { husk } \\
\text { (g/cob) }\end{array}$ & $\begin{array}{l}\text { Wt. Of } \\
\text { cob } \\
\text { without } \\
\text { husk } \\
\text { (g/cob) } \\
\end{array}$ & $\begin{array}{l}\text { Length of } \\
\text { cob without } \\
\text { husk (cm) }\end{array}$ & $\begin{array}{c}\text { Av. } \\
\text { Diameter } \\
\text { of cob } \\
\text { without } \\
\text { husk (cm) }\end{array}$ \\
\hline \multicolumn{8}{|l|}{ VARIETY (V) } \\
\hline $\mathrm{V}_{1}=\mathrm{RCM}-76$ & 12.96 & 25.81 & 328.01 & 239.62 & 191.62 & 17.21 & 2.84 \\
\hline$V_{2}=D A-61-A$ & 13.19 & 29.02 & 341.34 & 244.90 & 196.43 & 18.28 & 2.88 \\
\hline$\overline{\text { S.Ed.( }( \pm)}$ & 0.377 & 1.878 & 7.908 & 7.604 & 4.61 & 0.701 & 0.054 \\
\hline C.D (0.05) & NS & NS & NS & NS & NS & NS & NS \\
\hline \multicolumn{8}{|l|}{$\begin{array}{l}\text { INTEGRATED } \\
\text { NUTRIENT } \\
\text { MANAGEMENT } \\
\text { PRACTICES (I) }\end{array}$} \\
\hline$I_{1}=0 \mathrm{~kg} / \mathrm{ha}$ & 10.67 & 22.67 & 226.66 & 208.17 & 160.00 & 14.00 & 2.36 \\
\hline $\begin{array}{l}\mathrm{I}_{2}=\quad 60-40-40 \quad \mathrm{~kg} / \mathrm{ha} \\
(\mathrm{RDF})\end{array}$ & 12.28 & 25.17 & 289.04 & 230.17 & 184.33 & 15.90 & 2.67 \\
\hline $\begin{array}{l}\mathrm{I}_{3}=\mathrm{RDF}+\text { Azospirillum }+ \\
\text { PSB }\end{array}$ & 12.83 & 25.89 & 307.13 & 237.00 & 187.67 & 16.93 & 2.67 \\
\hline $\begin{array}{l}\mathrm{I}_{4}=\mathbf{5 0 \%} \mathbf{R D} \text { of } \mathbf{N} \\
\text { through fertilizer }+\mathbf{5 0 \%} \\
\text { replaced by VC }\end{array}$ & 13.22 & 27.78 & 337.19 & 251.50 & 199.50 & 18.25 & 2.97 \\
\hline $\begin{array}{l}\mathrm{I}_{5}=\mathbf{7 5} \% \mathrm{RD} \text { of } \mathrm{N} \text { through } \\
\text { fertilizer }+25 \% \text { replaced } \\
\text { by VC }\end{array}$ & 13.60 & 28.89 & 368.71 & 250.83 & 202.50 & 18.99 & 2.76 \\
\hline $\begin{array}{l}\mathrm{I}_{6}=50 \% \mathrm{RD} \text { of } \mathrm{N} \text { through } \\
\text { fertilizer }+\mathbf{5 0} \% \text { replaced } \\
\text { by EC }\end{array}$ & 14.72 & 30.94 & 412.61 & 260.17 & 215.17 & 20.37 & 3.40 \\
\hline $\begin{array}{l}\mathrm{I}_{7}=\mathbf{7 5 \%} \mathrm{RD} \text { of } \mathrm{N} \\
\text { through fertilizer }+25 \% \\
\text { replaced by EC }\end{array}$ & 14.22 & 30.56 & 401.37 & 258.00 & 209.00 & 19.76 & 3.21 \\
\hline S.Ed.( $( \pm)$ & 0.584 & 1.963 & 15.909 & 11.121 & 10.578 & 1.092 & 0.106 \\
\hline C.D. $(0.05)$ & 0.999 & 3.357 & 27.205 & 19.018 & 18.089 & 1.866 & 0.181 \\
\hline \multicolumn{8}{|l|}{ INTERACTION (V X I) } \\
\hline$\overline{\text { S.Ed.( }( \pm)}$ & 0.826 & 2.776 & 22.499 & 15.728 & 14.96 & 1.544 & 0.150 \\
\hline C.D.(0.05) & NS & NS & NS & NS & NS & NS & NS \\
\hline
\end{tabular}


Table.3 Effect of varieties and INM practices on 1000 grain weight (g), wt. of grain per cob (g) cob yield (q/ha), stover yield (q/ha) and harvest index (\%) of maize

\begin{tabular}{|c|c|c|c|c|c|}
\hline TREATMENT & $\begin{array}{c}1000 \text { grain } \\
\text { weight }\end{array}$ & $\begin{array}{l}\text { Wt. Of grain } \\
\text { per cob }(\mathrm{g})\end{array}$ & $\begin{array}{l}\text { Cob yield } \\
\text { (q/ha) }\end{array}$ & $\begin{array}{l}\text { Stover yield } \\
\text { (q/ha) }\end{array}$ & $\begin{array}{l}\text { Harvest } \\
\text { index }(\%)\end{array}$ \\
\hline \multicolumn{6}{|l|}{ VARIETY (V) } \\
\hline $\mathrm{V}_{1}=\mathrm{RCM}-76$ & 228.71 & 87.77 & 31.62 & 65.12 & 32.50 \\
\hline$V_{2}=D A-61-A$ & 230.71 & 92.17 & 33.00 & 65.33 & 33.30 \\
\hline S.Ed.( \pm$)$ & 0.149 & 1.00 & 1.540 & 1.820 & 1.051 \\
\hline C.D (0.05) & 0.435 & 2.92 & NS & NS & NS \\
\hline \multicolumn{6}{|l|}{$\begin{array}{l}\text { INTEGRATED } \\
\text { NUTRIENT } \\
\text { MANAGEMENT } \\
\text { PRACTICES (I) } \\
\end{array}$} \\
\hline$I_{1}=0 \mathrm{~kg} / \mathrm{ha}$ & 225.16 & 61.33 & 17.50 & 43.83 & 28.52 \\
\hline $\begin{array}{l}\mathrm{I}_{2}=60-40-40 \quad \mathrm{~kg} / \mathrm{ha} \\
(\mathrm{RDF})\end{array}$ & 227.05 & 71.62 & 29.50 & 59.92 & 33.10 \\
\hline $\begin{array}{l}\mathrm{I}_{3}=\mathrm{RDF}+\text { Azospirillum }+ \\
\text { PSB }\end{array}$ & 229.54 & 78.60 & 30.50 & 63.67 & 32.51 \\
\hline $\begin{array}{l}\mathrm{I}_{4}=\mathbf{5 0 \%} \mathbf{R D} \text { of } \mathrm{N} \\
\text { through fertilizer }+\mathbf{5 0 \%} \\
\text { replaced by VC }\end{array}$ & 230.74 & 92.63 & 35.50 & 66.48 & 34.83 \\
\hline $\begin{array}{l}\mathrm{I}_{5}=\mathbf{7 5} \% \mathrm{RD} \text { of } \mathrm{N} \text { through } \\
\text { fertilizer }+\mathbf{2 5 \%} \text { replaced } \\
\text { by VC }\end{array}$ & 231.00 & 97.76 & 36.17 & 71.12 & 33.80 \\
\hline $\begin{array}{l}\mathrm{I}_{6}=\mathbf{5 0} \% \mathrm{RD} \text { of } \mathrm{N} \text { through } \\
\text { fertilizer }+\mathbf{5 0 \%} \text { replaced } \\
\text { by EC }\end{array}$ & 233.16 & 117.65 & 39.83 & 78.42 & 33.75 \\
\hline $\begin{array}{l}\mathrm{I}_{7}=\mathbf{7 5 \%} \mathrm{RD} \text { of } \mathrm{N} \\
\text { through fertilizer }+25 \% \\
\text { replaced by } \mathrm{EC}\end{array}$ & 231.33 & 110.22 & 37.17 & 73.17 & 33.77 \\
\hline S.Ed.( \pm$)$ & 0.497 & 7.895 & 1.394 & 4.668 & 1.293 \\
\hline C.D. (0.05) & 0.849 & 13.50 & 2.384 & 7.982 & 2.212 \\
\hline \multicolumn{6}{|l|}{ INTERACTION (V X I) } \\
\hline S.Ed.( $( \pm)$ & 0.702 & 11.165 & 1.972 & 1.829 & 1.829 \\
\hline C.D.(0.05) & NS & NS & NS & NS & NS \\
\hline
\end{tabular}

Among the INM practices the best result was found in case of 50 percent RD of $\mathrm{N}$ through fertilizer +50 percent replaced by EC. This is due to increased availability of nutrients, vitamins, hormones and minerals from enriched compost. During the time of preparation rock phosphate, Azospirillum and PSB were used for enriching the enriched compost. Rock phosphate contains apatite which is a mineral form of calcium and one of the most important functions of calcium is to enhance the $\mathrm{NO}_{3}{ }^{-}$uptake. Azospirillum is a free living nitrogen fixing bacteria which promote plant growth. They colonize by adhesion, the root surface or the intercellular spaces of the host plant roots (McCully, 
2001). Azospirillum promote plant growth by several mechanisms including $\mathrm{N}$-fixation, phytohormone production such as auxins, gibberellins, cytokinins, nitric oxide as signals of plant growth promotion. PSB can solubilize the fixed soil $\mathrm{P}$ and applied phosphate resulting in higher crop yields. Phosphate $(\mathrm{P})$ and potassium $(\mathrm{K})$ solubilizing bacteria may enhance mineral uptake by plants through solubilizing insoluble $\mathrm{P}$ and releasing $\mathrm{K}$ from silicate in soil (Goldstein and Liu, 1987). Ultimately all these factors maintained a favourable soil physical, chemical and biological environment resulting better growth and development in yield attributes that ultimately had reflected in cob and stover yield of crop.

INM impoverished the soil physical chemical and biological characteristics as compared to control and RDF treatment. So, 50 per cent of $\mathrm{RD}$ of $\mathrm{N}$ through fertilizer +50 per cent $\mathrm{N}$ through enriched compost with DA-61-A variety is the best combination for cultivation of summer maize which will improve the yield of crop and also soil properties for succeeding crop.

\section{References}

Chandrashekara, C.P., Harlapur, S.I., Muralikrishna, S. and Girijesh, G.K. (2000). Response of maize to organic manure with inorganic fertilizers. Karnataka J. Agric. Sci. 13: 144-146.

Das, A., Prasad, M. and Gautam, R.C. (2004). Residual effect of organic and inorganic sources of nitrogen applied to cotton on succeeding wheat. Indian J. Agron., pp. 143-146.

Kumari, N., Singh, A., Pal, S.K. and Thakur, R. (2010). Effect of organic nutrient management on yield, nutrient uptake and nutrient balance sheet in scented rice (Oryza sativa). Indian J. Agron. 55(3): 220-223.

McCully, M.E. (2001). Niches for bacterial endophytes in crop plants: a plant biologist's review. Aust. J. plant Physiol. 28: 983-990.

Mugwe, J.D., Mugendi, J., Kungu and Muna, M.M. (2009). Maize yields response to application of organic and inorganic input under on-station and on-farm experiments in central Kenya. Exp. Agric. 45: 47-59.

Singh, R.B. (2000). Environmental consequences of agricultural development: a case study from the green revolution state of Haryana. Agric. Ecosyst. Env. 82(3): 97-103.

Syed Ismail, A.P.B., Shinde, G.G. and Deshmukh, A.S. (2001). Impact of FYM and fertilizer nitrogen on yield and soil properties of sorghum grown on Vertisol. Int. Sorghum Millets Newsl. 42: 29-31.

\section{How to cite this article:}

Krishnakhi Borah, Rinjumoni Dutta and Khagen Kurmi. 2018. Influence of Integrated Nutrient Management on Growth and Yield of Maize (Zea mays). Int.J.Curr.Microbiol.App.Sci. 7(05): 993-999. doi: https://doi.org/10.20546/ijcmas.2018.705.123 